\begin{tabular}{l} 
DURNAI, RISTIT \\
$\begin{array}{l}\text { (Rekayasa Sistem dan Teknologi Informasi) } \\
\text { Vol. } 6 \text { No. 1 (2022) } 41-46\end{array}$ \\
\hline
\end{tabular}

\title{
Prediksi Harga Saham Menggunakan BiLSTM dengan Faktor Sentimen Publik
}

\author{
Nurdi Afrianto ${ }^{1}$, Dhomas Hatta Fudholi ${ }^{2}$, Septia Rani ${ }^{3}$ \\ ${ }^{1}$ Program Studi Informatika Program Magister, Teknologi Industri, Universitas Islam Indonesia \\ ${ }^{2,3}$ Jurusan Informatika, Teknologi Industri, Universitas Islam Indonesia \\ ${ }^{1}$ nurdi.afrianto@students.uii.ac.id, ${ }^{2}$ hatta.fudholi@uii.ac.id*, ${ }^{3}$ septia.rani@uii.ac.id
}

\begin{abstract}
Stock market is one economic driver. It has roles in growth and development of a country. Stock is an attractive investment due to the huge profit. Many people buy and sell their stock. Stock investors try to choose the good investment company to get profits with small risk. Therefore, stock investors need to be careful and must evaluate a company. With machine learning technology, stock prediction problems can be solved. Deep learning is a subset of machine learning with own network. Deep learning has good performance in managing large amounts of data. This study used stock price history data and public sentiment data on a company. The method used in this research is Bidirectional Long-Short Term Memory (BiLSTM). The features used were closing price and compound score value of the public sentiment. Four scenarios were used in finding the best predictive model. The four scenarios use the same test data with different lengths of training data window. From the modelling, predictions with the model built using BiLSTM resulted in the smallest MSE value of 0.094 and the smallest RMSE value of 0.306 .
\end{abstract}

Keywords: stock market, deep learning, bidirectional lstm, public sentiment

\begin{abstract}
Abstrak
Pasar saham adalah salah satu penggerak ekonomi, pertumbuhan dan perkembangan suatu negara. Saham adalah investasi yang menarik karena mampu memberikan tingkat keuntungan yang besar. Investor saham berusaha memilih perusahaan investasi yang baik untuk mendapatkan keuntungan dengan resiko relatif kecil. Oleh sebab itu, para investor saham perlu memiliki ketelitian dan melakukan penilaian terhadap suatu perusahaan. Dengan teknologi pembelajaran mesin, permasalahan prediksi saham dapat diselesaikan. Deep learning adalah bagian dari pembelajaran mesin yang memiliki performa baik dalam mengelola data dengan jumlah banyak. Penelitian ini membangun model prediksi memakai data histori harga saham dan data sentimen publik pada suatu perusahaan. Metode yang digunakan pada penelitian ini adalah Bidirectional Long-Short Term Memory (BiLSTM). Fitur yang digunakan adalah harga penutup dan nilai compound score dari sentimen publik yang ada. Dalam mencari model prediksi terbaik, empat skenario digunakan dalam penelitian ini. Keempat skenario tersebut menggunakan data uji yang sama dengan panjang data latih yang berbeda dari sisi panjang jendela datanya. Pada pemodelan yang dilakukan, prediksi dengan model yang dibangun menggunakan BiLSTM menghasilkan nilai MSE terkecil 0.094 dan nilai RMSE terkecil 0.306 .
\end{abstract}

Kata kunci: pasar saham, deep learning, bidirectional 1stm, sentimen publik

\section{Pendahuluan}

Pertumbuhan ekonomi Indonesia mengalami penurunan dari $5.2 \%$ pada tahun 2019 menjadi $2.1 \%$ pada tahun 2020 [1]. Pertumbuhan ekonomi melemah karena aktivitas konsumsi dan investasi yang menurun. Ekonomi dan bisnis melemah disebabkan ketidakpastian global (Bank Indonesia) [2]. Pandemi covid - 19 membuat ekonomi semakin tidak menentu.
Pasar modal penting sebagai penggerak ekonomi, pertumbuhan, dan perkembangan suatu negara dalam modal jangka Panjang [3]. Pasar modal mempunyai dua fungsi dalam peranan perekonomian. Pasar modal sebagai sarana pendanaan usaha dari segi perusahaan dan pasar modal sebagai alat investasi pada bidang keuangan [4]. Oleh karena itu, pasar modal memiliki pengaruh dalam pertumbuhan ekonomi dan pengangguran PDB (Produk Domestik Bruto) [5]. Pasar 
modal berguna sebagai pembiayaan alternatif bagi perusahaan dan investasi bagi investor. Pasar modal memiliki dasar hukum yaitu Undang-undang Nomor 8 Tahun 1995 tentang pasar modal [6]. Investasi dalam pasar modal meliputi reksadana, saham, dan surat berharga negara. Pertumbuhan investor pasar modal meningkat $44 \%$ pada bulan juni 2018 sampai bulan juni 2019 [7]. Investor pasar modal tumbuh dari 1.369.810 investor menjadi 1.971.213 investor baru [7]. Karena mendapatkan keuntungan menjanjikan, transaksi jual beli saham sering dilakukan orang. Investor saham berusaha memilih perusahaan investasi yang baik untuk mendapatkan keuntungan dengan resiko yang relatif kecil. Sehingga, para investor saham perlu memiliki ketelitian dan melakukan penilaian terhadap suatu perusahaan.

Penelitian [8] menggunakan metode linear regresi untuk memprediksi pergerakan harga saham. Dataset yang digunakan adalah Tata Consultancy Historical (TCS) di India. Harga pembuka, harga tertinggi, harga terendah, dan jumlah tren digunakan sebagai variabel independent input. Harga penutup digunakan sebagai variabel dependent target. Linear regresi memiliki nilai confidence 0.97 sedangakan metode polynomial sebesar 0.468 dan RBF sebesar 0.5652 .

Penelitian [9] menggunakan metode regresi linear dalam memprediksi harga saham perusahaan. Penelitian ini menggunakan data saham bank BCA saham bank BCA selama tahun 2015 sampai dengan 2017. Tools SPPSS 16.0 digunakan dalam pengambilan data saham perusahaan bank BCA. Evaluasi model menggunakan Moving Average Percentage Error (MAPE). Persentase error yang stabil dan linear didapatkan pada tahun 2017. Nilai error yang paling baik didapatkan pada tahun 2015 dengan error dibawah rata-rata 100,00 adalah 57,57 .

Penelitian [10] menggunakan metode multiple linear regression untuk prediksi saham. Data yang digunakan adalah Jakarta Composite Index (JCI). Metode multiple linear regression mendapatkan nilai mean square error sebesar 15087.465, nilai root mean square error sebesar 122.831, serta nilai mean absolute percentage error sebesar 3.255.

Penelitian tentang prediksi saham berkembang dengan menggunakan metode data mining dan deep learning. Data saham bersifat deret waktu sehingga model deep learning mengungguli model linear [11]. Penelitian [12] memakai model Recurrent Neural Network (RNN) dalam memperkirakan suatu pergerakan harga saham. Model menggunakan dataset harga penutup saham Advanced Micro Device (AMD). Dataset selama 156 hari digunakan untuk pelatihan dan 12 hari untuk data uji. Peneliti menggunakan Beberapa library seperti numpy, pandas, Scikit-learn dan tensorflow dalam membangun model. Model dibangun menggunakan neuron 500 dan iterasi sebanyak 5000. Model mendapatkan hasil mean squared error (MSE) dibawah $5 \%$.

Peneliti [13] menggunakan metode Recurrent Neural Network (RNN) untuk memprediksi saham. Dataset yang digunakan menggunakan data (harga open, harga close, harga high, harga low, amount dan volumns) pada saham Shanghai Shenzhen CSI 300. Data yang digunakan selama periode januari 2016 sampai desember 2016. Metode RNN (Recurrent Neural Network) dibandingkan dengan model lain seperti SVM (Support Vector Machines), random forest dan logistic regresi. Model RNN mendapatkan nilai profitabilitas sebesar 24.50\%. SVM (Support Vector Machines) mendapatkan nilai profitabilitas sebesar $12.93 \%$. Random forest mendapatkan nilai profitabilitas $9.65 \%$. Logistic regresi mendapatkan nilai profitabilitas sebesar $13.37 \%$.

Penelitian [14] menggunakan harga Adjacent Close dari saham S\&P 500. Model dibangun menggunakan beberapa jenis LSTM antara lain, model Deep Long Short-Term Memory (DLSTM), model Long ShortTerm Memory Projected (LSTMP), dan model Deep Long Short-Term Memory Projected (DLSTMP). Loss function digunakan adalah Mean Squared Error (MSE) dan optimasisasi Adam. Model Long Short-Term Memory Projected (LSTMP) setelah melakukan proses 3 epoch mendapatkan nilai MSE sebesar 0.5770. Pada Model Deep Long short-term memory (DLSTM) setelah melakukan proses 3 epoch mendapatkan nilai Mean squared error (MSE) 0.00031464 dan terpilih menjadi model terbaik. Model Deep Long short-term memory (DLSTM) memiliki arsitektur berupa cells 128 dan layer 2 dan akan diterapkan pada saham AAPL, GOOG dengan epoch 10.

Pada penelitian ini, penulis memanfaatkan sentimen publik pada saham. Model dibangun dengan metode Bidirectional Long Short-Term Memory (BLSTM) dengan menambahkan sentimen publik pada proses training dan testing. Algoritma VADER (Valence Aware Dictionary and sEntiment Reasoner) digunakan pada sentimen publik untuk mengetahui seberapa positif dan negative dari suatu kalimat [15]. LQ45 adalah indeks saham yang berisi 45 perusahaan besar dengan prospek bisnis bagus. Bank Central Asia termasuk salah satu anggota saham LQ45. Penelitian ini menggunakan data saham perusahaan Bank Central Asia (BBCA). Data sentimen publik bersumber dari twitter sedangkan data saham bersumber dari yahoo finance. Peneliti menggunakan skor Mean squared error (MSE), skor Root Mean Square Error (RMSE) dan directional statistics (Dstat) untuk evaluasi model yang dibangun. Fokus penelitian yang dilakukan adalah pada pengembangan model prediksi dan tidak pada pembangunan sistem rekomendasi jual beli saham.

DOI: https://doi.org/10.29207/resti.v6i1.3676

Lisensi: Creative Commons Attribution 4.0 International (CC BY 4.0) 


\section{Metode Penelitian}

Dalam penelitian ini, ada beberapa tahap yang harus dilewati dengan baik. Tahapan penelitian yang dilakukan meliputi pengumpulan data berupa data saham dan sentimen publik, preprocessing data, perancangan, implementasi dan evaluasi. Diagram Alir penelitian dapat dilihat pada Gambar 1.

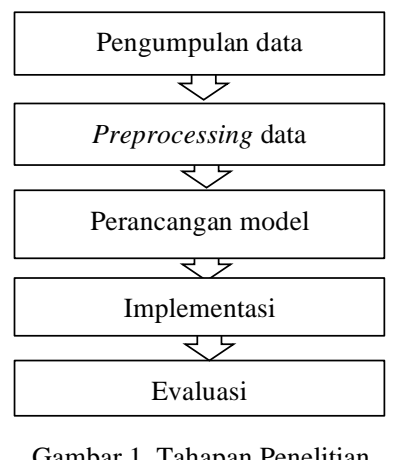

Penelitian ini menggunakan data saham perusahaan Bank BCA (BBCA). Data saham diambil dalam situs Yahoo Finance. Data saham yang diambil adalah data saham pada hari perdagangan saham tersebut aktif. Data saham tidak terdapat pada hari tutup perdagangan seperti hari Sabtu dan Minggu. Sentimen publik diambil dari Twitter. Data Twitter yang digunakan adalah tweet yang mengandung ticker (\$) saham dan diikuti dengan kode nama perusahaan (\$BBCA). Tidak ada pembatasan user tertentu dalam tweet yang dipilih. Data dikumpulkan selama kurang lebih 1 tahun 8 bulan mulai dari 19 Februari 2020 sampai dengan 29 September 2021.

Preprocessing data bertujuan agar data sesuai dengan format penelitian. Preprocessing yang dilakukan berfokus pada data twitter dan proses yang dilakukan adalah case folding, tokenisasi, Normalization, filtering stopword removal dan lematization. Selain itu, data Twitter disaring sehingga hanya menyisakan data Twitter pada hari aktif perdagangan saham saja.

Data fitur dari twitter dan saham yang digunakan, yaitu data harga penutup dan nilai sentimen, dinormalisasi menggunakan metode Min-Max normalization. Metode ini menormalisasi data dengan mentrasformasi linear data asli. Min-Max normalization dapat menghasilkan keseimbangan antara nilai data sebelum dan sesudah di normalisasi.

Tahap perancangan model memiliki dua komponen utama, yaitu BiLSTM (Bidirectional Long Short-Term Memory) sebagai arsitektur dasar dari pengembangan model prediksinya dan VADER (Valence Aware Dictionary and sEntiment Reasoner) sebagai algoritma perhitungan nilai sentimen publiknya.

BiLSTM memanfaatkan konteks informasi sebelumnya dan konteks informasi setelahnya dengan memproses data dari arah berlawanan dengan hidden layer terpisah
[16]. BILSTM (Bidirectional Long Short-Term Memory) dikatakan tumpukan dari LSTM (Long ShortTerm Memory), forward layer digunakan untuk konteks informasi sebelumnya, dan backward layer digunakan untuk konteks informasi setelahnya [17] . Ilustrasi Bidirectional Long Short-Term Memory bisa dilihat pada Gambar 2. Gambar 2 memperlihatkan setiap hidden layer keluaran komponen pada layer bawah dan atas bergabung sehingga membentuk nilai fitur yang lebih panjang dibandingkan LSTM (Long Short-Term Memory). Panjang fitur mengakibatkan informasi yang diproses pada tahap feed forward neural dapat mengklasifikasikan dengan lebih detail.

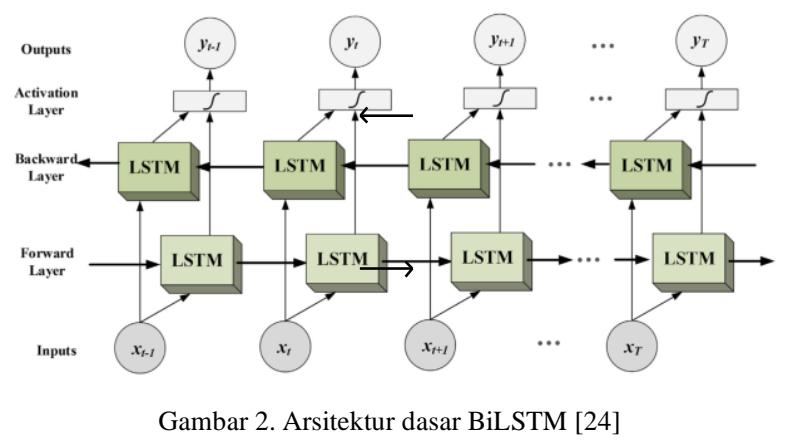

VADER adalah algoritma yang menggunakan lexicon untuk mengklasifikasikan sentimen berdasarkan intensitas sentimen [18]. Perhitungan sentimen dengan metode ini memiliki empat komponen nilai yaitu positif, negatif, netral dan compound score. Compound score adalah jumlah keseluruhan skor positif, negatif dan netral yang telah dinormalisasi antara -1 dan +1 . Jika compound score $>=0.05$ maka sentiment positif, jika nilai compound score $>-0.05$ dan nilai compound score $<0.05$ maka sentimen netral, jika nilai compound score $<=-0.05$ maka sentimen negative [19].

Implementasi pembangunan model prediksi dilakukan dengan empat skenario yang berbeda dari sisi jangkauan jendela batas waktu data yang digunakan. Keempat skenario ini memiliki data tes yang sama, yaitu data pada rentang waktu dari 18-8-2021 hingga 29-9-2021, dengan kurang lebih berjumlah 30 data. Jangkauan tanggal data latih pada keempat skenario tersebut adalah:

a. Skenario 1: 5-7-2021 s/d 16-8-2021 (30 data)

b. Skenario 2: 5-4-2021 s/d 16-8-2021 (90 data)

c. Skenario 3: 19-11-2020 s/d 16-8-2021 (180 data)

d. Skenario 4: 19-2-2020 s/d 16-8-2021 (360 data)

Hasil prediksi yang didapatkan dari implementasi pemodelan dengan empat skenario tersebut selanjutnya memasuki tahapan pengujian untuk mengukur akurasinya. Pengujian yang dilakukan dalam penelitian ini menggunakan Mean Square Error (MSE) dan Root Mean Square Error (RMSE).

MSE adalah rata-rata kesalahan kuadrat diantara nilai data aktual dan peramalan. Mean Square error

DOI: https://doi.org/10.29207/resti.v6i1.3676

Lisensi: Creative Commons Attribution 4.0 International (CC BY 4.0) 
didasarkan pada selisih nilai data aktual dengan data peramalan. Nilai kemudian dikuadratkan serta dijumlahkan secara keseluruhan dan dibagi dengan banyak data yang ada. Perhitungan MSE dapat dilihat pada persamaan (1), dengan Aktual adalah data sebenarnya, prediksi adalah nilai prediksi dari variable Aktual, dan $n$ banyaknya observasi.

$$
M S E=\frac{\sum(\text { Aktual }- \text { Prediksi })^{2}}{n}
$$

$R M S E$ adalah perhitungan akar dari kuadrat error (data aktual - data prediksi) yang dibagi dengan jumlah data. Rumusan RMSE pada persamaan (2), dengan Aktual adalah data sebenarnya, prediksi adalah nilai prediksi dari variable Aktual dan $n$ banyaknya obsevasi.

$$
R M S E=\sqrt{\frac{\sum(\text { Aktual-Prediski })^{2}}{n}}
$$

Selain pengukuran kesalahan prediksi, kriteria penting lain yang dapat membantu investor dalam pengambilan keputusan adalah arah gerak peramalan. Kemampuan untuk meramalkan arah pergerakan peramalan dapat diukur dengan menggunakan directional statistics (Dstat) [20]. Perhitungan directional statistics (Dstat) ditunjukkan pada persamaan (3) dan (4), dimana $n$ adalah jumlah data pelatihan, $x$ adalah data aktual, dan $\hat{x}$ adalah output peramalan. Nilai directional statistics (Dstat) yang besar menandakan semakin baik akurasi prediksi.

$$
\begin{aligned}
& \text { Dstat }=\left(\frac{1}{n} \sum_{t=1}^{n} a_{t}\right) \times 100 \% \\
& a_{t}=1 \begin{cases}1 & \left(x_{t+1}-x_{t}\right)\left(\hat{x}_{t+1}-x_{t}\right) \geq 0 \\
0 & \left(x_{t+1}-x_{t}\right)\left(\hat{x}_{t+1}-x_{t}\right)<0\end{cases}
\end{aligned}
$$

\section{Hasil dan Pembahasan}

Data saham yang diambil dari Yahoo Finance memiliki rentang pengambilan dari tanggal 19 Februari 2020 sampai dengan 29 September 2021. Data awal yang diambil memiliki atribut date, open, high, low, dan close.

Data tweet yang menjadi representasi dari sentimen publik, diambil pada tanggal yang sama dengan data perdagangan saham yang diambil sebelumnya. Contoh data teks tweet yang didapatkan adalah '\$BBCA ama \$TLKM all in nih wkwkwkwk', 'Masih belom tergoda 12.12 demi nambah lot \$BBCA... Yoh iso yohh', dan '\$BBCA \& \$DMAS tunggu window dressing, kalau kuat tahan smp akhir tahun baru CL'.

Untuk mengimplementasikan pemodelan, penelitian ini menggunakan perangkat keras dengan spesifikasi CPU core i5 8250U, RAM sebesar 12 GB dan framework tensorflow dengan versi 2.4.0. Tabel 1 menunjukkan kombinasi parameter untuk setiap skenario pemodelan. Hidden layer merupakan jumlah lapisan tersembunyi diantara input layer dan output layer. Neuron menunjukkan jumlah neuron di dalam hidden layer.
Epoch adalah banyaknya siklus penuh forward dan backward untuk semua data latih. Batch size merupakan banyaknya sampel data yang masuk pada setiap iterasi batch nya. Jumlah epoch dan batch size yang dipilih mengacu kepada [21]. Masing-masing model menggunakan optimasi Adam. Pada tabel yang sama, kita dapat melihat hasil nilai loss pada epoch terakhir pelatihan. Skenario pertama memiliki nilai loss terendah yang diikuti oleh skenario ketiga, kedua, dan keempat, dengan nilai loss sebesar 0.0141, 0.0187, 0.0118, dan 0.0033. Gambar 3 menunjukkan grafik loss dalam proses pelatihan keempat skenario yang ada.

\begin{tabular}{llllll}
\multicolumn{5}{c}{ Tabel 1. Parameter dan Loss Pemodelan } \\
\hline Skenario & $\begin{array}{l}\text { Hidden } \\
\text { Layer }\end{array}$ & Neuron & Epoch & $\begin{array}{l}\text { Batch } \\
\text { size }\end{array}$ & Loss \\
\hline 1 & 4 & 2000 & 205 & 32 & 0.0141 \\
2 & 4 & 2000 & 205 & 32 & 0.0187 \\
3 & 4 & 2000 & 205 & 32 & 0.0118 \\
4 & 4 & 2000 & 205 & 32 & 0.0033 \\
\hline
\end{tabular}

Data yang digunakan untuk melakukan evaluasi adalah data selama satu bulan, dari tanggal 30/08/2021 sampai dengan 29/09/2021. Evaluasi yang dilakukan pada penelitian ini menitikberatkan pada nilai MSE dan RMSE dan Dstat dari hasil prediksi model yang dikembangkan.

Tabel 2 menunjukkan hasil pengujian dari keempat model yang dibangun. Nilai MSE dan RMSE dari keempat model yang dibangun tidak terlampau jauh. Nilai terendah dari MSE dan RMSE didapatkan pada model Skenario 4 dengan nilai 0.094 dan 0.306. Oleh karena itu, dari sisi perhitungan MSE dan RMSE, kita dapat melihat bahwa Skenario 4 dengan penggunaan data latih 1 tahun memberikan hasil prediksi dengan nilai error terendah. Pun demikian, jika kita melihat nilai Dstat dari masing-masing model, maka kita akan melihat nilai Dstat yang tidak berbanding lurus dengan nilai MSE dan RMSE. Nilai Dstat tertinggi didapatkan oleh model pada Skenario 1 dengan nilai $68 \%$.

Grafik hasil prediksi harga saham pada keempat skenario model dapat dilihat pada Gambar 4. Garis berwarna biru merepresentasikan hasil prediksi dan garis berwarna merah merepresentasikan nilai saham riil. Pada gambar tersebut, terlihat bahwa pola prediksi dari harga saham yang paling menyerupai pola harga riil nya adalah model dari skenario 1 dan 2 . Hal ini dapat menjadi justifikasi tingginya nilai Dstat yang didapatkan pada skenario 1 dan 2 dibanding dengan skenario yang lain.

\begin{tabular}{llll}
\multicolumn{3}{l}{ Tabel 2. Hasil Pengujian Empat Skenario Model } \\
\hline Skenario & MSE & RMSE & Dstat \\
\hline 1 & 0.133 & 0.364 & 68 \\
2 & 0.123 & 0.351 & 64 \\
3 & 0.107 & 0.327 & 44 \\
4 & 0.094 & 0.306 & 55.55 \\
\hline
\end{tabular}

DOI: https://doi.org/10.29207/resti.v6i1.3676

Lisensi: Creative Commons Attribution 4.0 International (CC BY 4.0) 
Dengan melihat hasil yang didapatkan pada Tabel 2 dan Gambar 4, serta nilai MSE dan RMSE yang tidak terlampau jauh, model yang dibangun pada Skenario 1 dan 2 menjadi alternatif yang lebih baik dengan memberikan gambaran perubahan nilai yang menyerupai nilai riil saham yang ada.
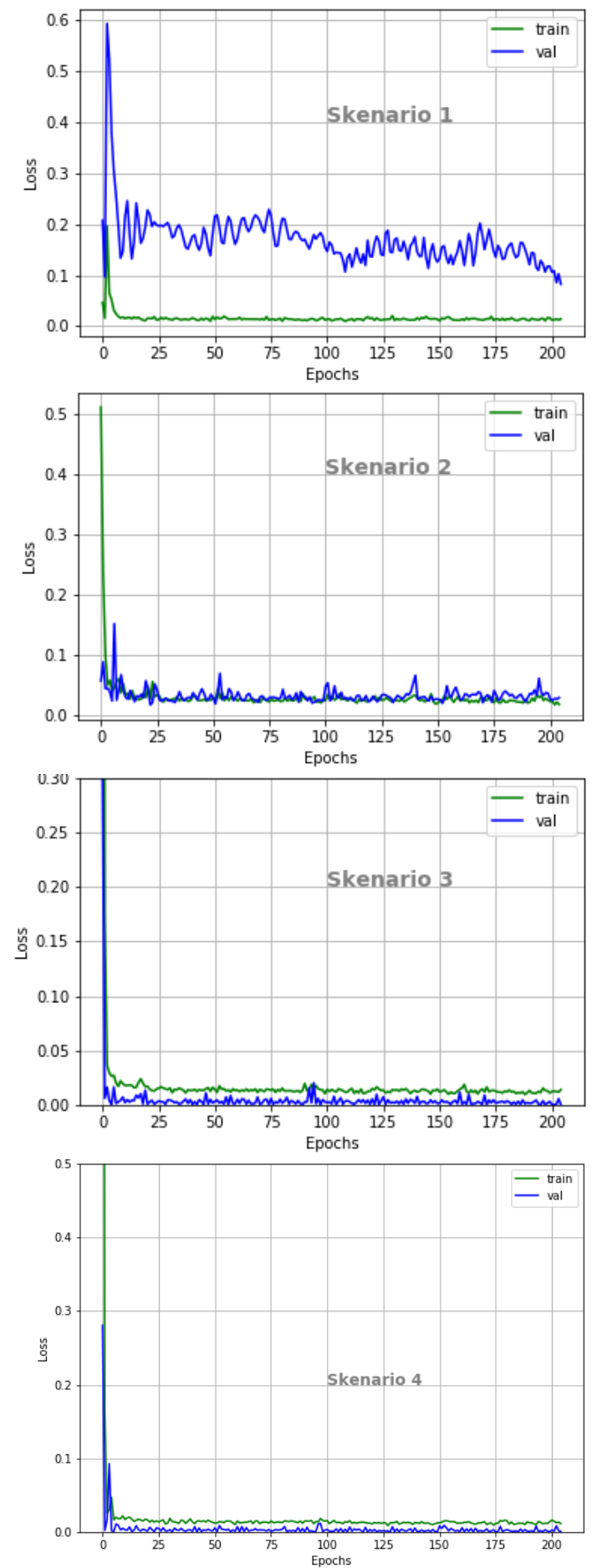

Gambar 3. Nilai loss pada proses pelatihan
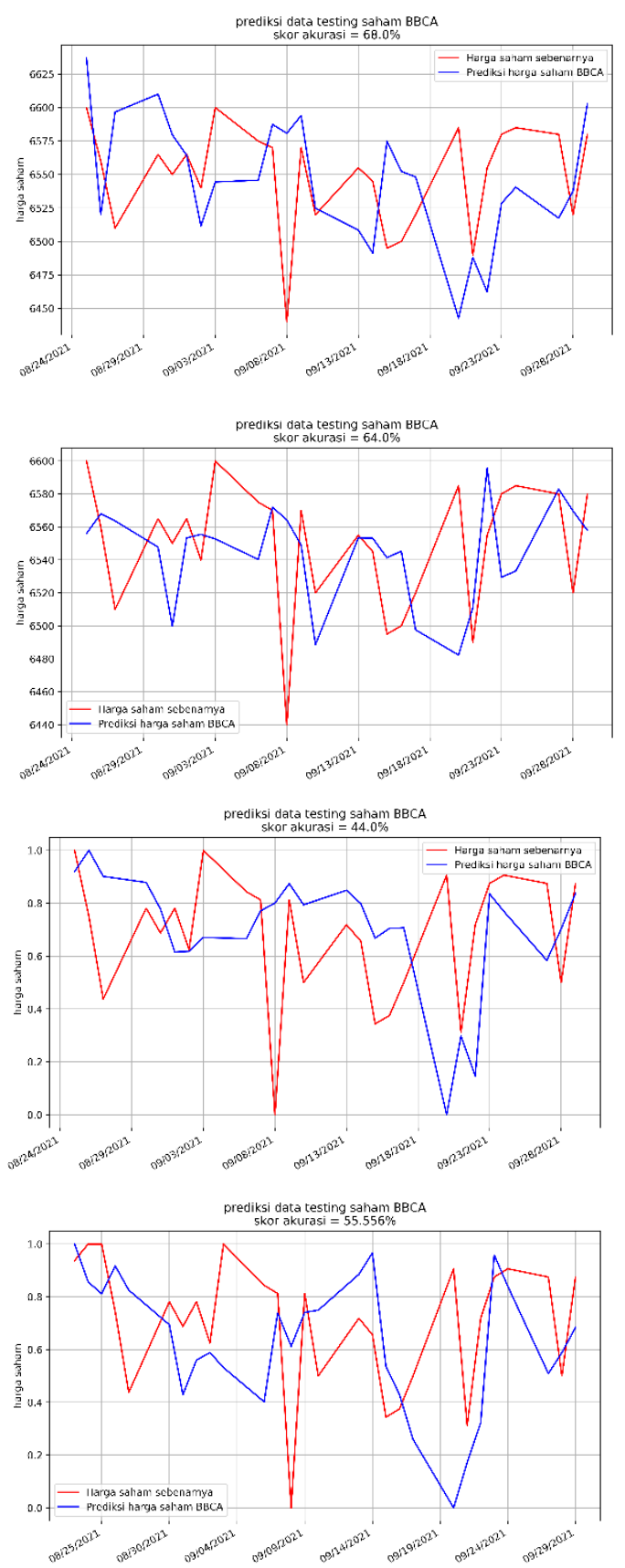

Prediksi _ : Riil

Gambar 4. Hasil prediksi Skenario 1, 2,3, dan 4 (atas ke bawah)

\section{Kesimpulan}

Penelitian ini mempunyai tujuan untuk membangun model prediksi harga saham dengan Bidirectional Long-Short Term Memory. Dalam mengembangkan model prediksi, peneliti menambahkan faktor sentimen publik pada studi kasus saham yang diangkat. Penelitian menggunakan fitur harga penutup saham dan

DOI: https://doi.org/10.29207/resti.v6i1.3676

Lisensi: Creative Commons Attribution 4.0 International (CC BY 4.0) 
nilai compound score dari sentimen publik. Dalam pelatihan model yang dibangun, ada empat skenario yang disusun. Perbedaan dari masing-masing skenario adalah panjang jumlah data latih yang digunakan. Evaluasi model dilakukan dengan menghitung MSE, RMSE, dan Dstat. Skenario 4 dengan menggunakan data latih sepanjang kurang lebih 1 tahun memberikan hasil prediksi dengan nilai eror terendah yaitu 0.094 untuk MSE dan 0.306 untuk RMSE. Pun demikian, nilai Dstat tertinggi didapatkan oleh model pada Skenario 1 dengan nilai $68 \%$.

Sebagai saran pengembangan ke depan dari penelitian ini, terdapat faktor lain yang mungkin menentukan pergerakan harga saham, misalnya laporan keuangan, rasio keuangan, pajak, kebijakan pemerintah, informasi kurs serta pergerakan fiskal. Faktor-faktor ini dapat dijadikan sebagai fitur tambahan dengan target harapan untuk memperkecil nilai MSE dan RMSE, sehingga prediksi menjadi lebih akurat.

\section{Ucapan Terimakasih}

Penelitian ini didanai oleh Hibah Penelitian Tesis Magister RISTEKDIKTI dengan no 081/SP2H/AMD/LT/DRPM/2020.

\section{Daftar Rujukan}

[1] Word Bank, "Indonesia Economic Prospects The Long Road to Recovery," 2020. [Online]. Available: http://documents1.worldbank.org/curated/en/8047915948268 69284/pdf/Indonesia-Economic-Prospects-The-Long-Roadto-Recovery.pdf.

[2] Y. Sumarni, "Pandemi Covid 19: Tantangan Ekonomi dan Bisnis," Al-Intaj J. Ekon. dan Perbank. Syariah, vol. 2, no. 1, pp. 46-58, 2020.

[3] Osaze BE, The Nigeria Capital Market in the African and Global Financial System. Benin City: Bofic Consults Group Limited., 2000.

[4] Y. S. J. Nasution, "Peranan Pasar Modal Dalam Perekonomian Negara," Hum. FALAH J. Ekon. dan Bisnis Islam, vol. 2, no. 1, pp. 95-112, 2015.

[5] E. Suchy and M. Soltes, "Influence of Capital Market on the US Unemployment and GDP," Int. Sci. Conf., pp. 708-714, 2018.

[6] C. P. Permata and M. A. Ghoni, "Peranan Pasar Modal Dalam Perekonomian Negara Indonesia," J. Akun Stie, vol. 5, no. 2, pp. 50-61, 2019.

[7] PT Kustodian Sentral Efek Indonesia, "Pertumbuhan Single Investor Identification (SID)," Indonesia, 2019. [Online]. Available:

https://www.ksei.co.id/files/uploads/fokuss_bulletins/fokuss_ file/id-id/58_edisi_2_20190902150110.pdf.

[8] D. Bhuriya, G. Kaushal, A. Sharma, and U. Singh, "Stock market predication using a linear regression," Proc. Int. Conf. Electron. Commun. Aerosp. Technol. ICECA 2017, vol. 2017Janua, pp. 510-513, 2017, doi: 10.1109/ICECA.2017.8212716.
[9] M. Merfin and R. S. Oetama, "Prediksi Harga Saham Perusahaan Perbankan Menggunakan Regresi Linear Studi Kasus Bank BCA Tahun 2015-2017," Ultim. J. Tek. Inform., vol. 11, no. 1, pp. 11-15, 2019, doi: 10.31937/ti.v11i1.1239.

[10] A. Izzah, Y. A. Sari, R. Widyastuti, and T. A. Cinderatama, "Mobile app for stock prediction using Improved Multiple Linear Regression," Proc. - 2017 Int. Conf. Sustain. Inf. Eng. Technol. SIET 2017, vol. 2018-Janua, pp. 150-154, 2017, doi: 10.1109/SIET.2017.8304126.

[11] M. Hiransha, E. A. Gopalakrishnan, V. K. Menon, and K. P. Soman, "NSE Stock Market Prediction Using Deep-Learning Models," Procedia Comput. Sci., vol. 132, no. Iccids, pp. 1351-1362, 2018, doi: 10.1016/j.procs.2018.05.050.

[12] I. Jahan and S. Sajal, "Stock Price Prediction using Recurrent Neural Network (RNN) Algorithm on Time-Series Data," 2018.

[13] Zhichen Lu, Wen Long, and Ying Guo, Extreme Market Prediction for Trading Signal with Deep Recurrent Neural Network, vol. 1. Beijing, Republic of China: School of Economics and Management, University of Chinese Academy of Sciences, 2018.

[14] R. Mathur, V. Pathak, and D. Bandil, Stock Market Price Prediction Using LSTM RNN, vol. 841. 2019.

[15] V. Bonta, N. Kumaresh, and N. Janardhan, "A Comprehensive Study on Lexicon Based Approaches for Sentiment Analysis," Asian J. Comput. Sci. Technol., vol. 8, no. S2, pp. 1-6, 2019, doi: 10.51983/ajcst-2019.8.s2.2037.

[16] M. Maimaiti, A. Wumaier, K. Abiderexiti, and T. Yibulayin, "Bidirectional long short-term memory network with a conditional random field layer for Uyghur part-of-speech tagging," Inf., vol. 8, no. 4, pp. 1-12, 2017, doi: 10.3390/info8040157.

[17] G. Lample, M. Ballesteros, S. Subramanian, K. Kawakami, and C. Dyer, "Neural architectures for named entity recognition," 2016 Conf. North Am. Chapter Assoc. Comput. Linguist. Hum. Lang. Technol. NAACL HLT 2016 - Proc. Conf., pp. 260-270, 2016, doi: 10.18653/v1/n16-1030.

[18] H. R. M., S. D. . Harish Rao M, Shashikumar D.R, "Automatic Product Review Sentiment Analysis Using Vader and Feature Visulaization," Int. J. Comput. Sci. Eng. Inf. Technol. Res., vol. 7, no. 4, pp. 53-66, 2017, doi: 10.24247/ijcseitraug20178.

[19] M. Karim and S. Das, "Sentiment Analysis on Textual Reviews," IOP Conf. Ser. Mater. Sci. Eng., vol. 396, no. 1, 2018, doi: 10.1088/1757-899X/396/1/012020.

[20] K. K. Lai, L. Yu, S. Wang, and W. Huang, "Hybridizing Exponential Smoothing and Neural Network," Int. Conf. Comput. Sci., pp. 493-500, 2006.

[21] A. Kumar, K. Purohit, and K. Kumar, "Stock Price Prediction Using Recurrent Neural Network and Long Short-Term Memory," Lect. Notes Networks Syst., vol. 175, no. February, pp. 153-160, 2021, doi: 10.1007/978-3-030-67187-7_17.

[22] R. Irmanita, Sri Suryani Prasetiyowati, and Yuliant Sibaroni, "Classification of Malaria Complication Using CART (Classification and Regression Tree) and Naïve Bayes", RESTI, vol. 5, no. 1, pp. 10 - 16, Feb. 2021. https://doi.org/10.29207/resti.v5i1.2770

[23] Dwi Kartini, Friska Abadi, and Triando Hamonangan Saragih, "Prediksi Tinggi Permukaan Air Waduk Menggunakan Artificial Neural Network Berbasis Sliding Window", RESTI, vol. 5, no. 1 , pp. $39-44$, Feb. 2021. https://doi.org/10.29207/resti.v5i1.2602

[24] Ö. Yildirim, "A novel wavelet sequences based on deep bidirectional LSTM network model for ECG signal classification," Comput. Biol. Med., vol. 96, no. March, pp. 189-202, 2018, doi: 10.1016/j.compbiomed.2018.03.016. 